\title{
Hindu Illumination Learning Model Development Based Spiritual Tour Guide
}

\author{
I Putu Suarnaya \\ STKIP Agama Hindu Singaraja Bali, Indonesia \\ suarnayaiputu@gmail.com
}

\begin{abstract}
The purpose of the study was to design Hindu illumination conceptual learning model based spiritual tour guide in Hindu illumination department, to find out expert validity of Hindu illumination conceptual learning model based spiritual tour guide developed in Hindu illumination department. The university students of Hindu illumination Department in STKIP Agama Hindu Singaraja were the populationof the present study through purposive sampling technique, only 10 students were taken from the population of $4^{\text {th }}$ semester, the data were collected by using observation, interview, documentation, assessmentrubric, and questionnaire. The data which were achieved then analized qualitatively by using Miles' and Huberman's interactive data analysis methode. Whereas, the result of the data from assessment rubric were analyzed by using interrater agreement model method or Gregory Formula. The result of this present study was syntax of the learning model Dharma Sedhana; Dharma Yatra; Dharma Santi; Dharma Wacana; The conclution of the present study article presented above was revealed that developed and produced 6 Hindu illumination learning models based spiritual tour guide. Descriptively, it was found that the mean scores of the learning expert to the Quality of Hindu illumination learning model based spiritual Tour Guide was catagorized very well, where the Quality of this learning seriously bridge the university student to discover self-potential to become a Qualified investigator for Hindu's people.
\end{abstract}

Keywords: learning model, illumination, spiritual tour guide

\section{INTRODUCTON}

Hindu Department school of teacher training and education (STKIP) Singaraja is one of Hindu education school located in north Bali of Buleleng regency which execute main duty to educate Qualified Hindu's teacher candidates. Beside that, STKIP of Hindu department also has a department which educate its alumnus to become Hindu's investigator cadre with knowledge and competitive capacity in locat, national, to international scale. Beside as a Hindu investigator, they are also hopefully be a trade on spiritual tour guide, it is Hindu Illumination Department (PAH) agree with judgment letter of Dirjen Bimas Hindu Kementrian Agama No. 164 year 2011.

Although it is still a new department, it's target always want to efort the standard Quality of learning especially in illumination Quality and Quantity. One of the steps have been done by giving Hindu illumination Technique lecture. It is clustered in work skill lecture. In order to the university students could do the duty as Hindu investigator accordance with good programe and plan, so the duties done by a religion investigator could touch the inner hearth of people to understand, thoughtful, and deed Hindu's doctrine as good as possible. The matter explained at Hindu illumination technique lecture teach about details and duties of an Hindu investigator. Its will useful the university students which enter to society to do the duties as Hindu investigator.

Beside that, the alumnusare expected to be a spiritual tour guide. It is related with tourism development in Bali especially special tourism interest (spiritual tourism ) which became new trend when in reality it is interested by the tourists due to find peace and harmony such as holly travel or Tirta Yatra to Kahyangan Jagat temples ( Pitana, 2012 ).

Accordance to the raising of spiritual tourism interest is not supported by fulfillment of the spiritual tour guide which understand Hindu and local culture complications well. For the examples about temple history, relation between one temple with others, ceremonies and its meaning, kinds and function of ceremonies (banten), kinds of building and its function how the temples preserve, and how to get religious value deeply especially in increasing spiritual moral value. So if these things are not understood well, it will make miss information for the tourists and appear bad impact.

This opportunity can be developed well by Hindu illumination department, where the alumnus' chance to become a spiritual tour guide is openedwidely. Certainly, to get this target is not so simple, where there are many obstacles faced by the university students and the lectures in Hindu illumination department such as, learning strategi, learning media, comprehensive supporting books as main source books subject, communication technique in information delivery, and direct practice done by the university students.

In addition, it is important to master foreign language well due to many spiritual tour interests come from other country. Mastery of language function to information delivery process it self where it commonly happen in a communication media, in this case language as symbol which mostly used, in verbal and non verbal languages.

Concerning the above problem, it is needed a development model which can integrate between Hindu illumination technique, mastery of foreign language, and spiritual tour guide concept. By then it is expected that one of the models will be developed is Hindu illumination learning model based spiritual tour guide in Hindu illumination Department.

\section{METHODS}

Since this study aimed at development, the most appropriate procedure developed for this study was thus a development research method (R \& D). Hindu illumination tecture of sylabus design based spiritual tour guide was developed as a result in this study. This study adopted R \& D model design by Frankel (1990), which state three common steps such as: (1) itroducing study; (2) development study; and (3) evaluation. The data which were needed in this study where collected 
through observation, interview, documentation, assessment rubric, and questionare. The data which were achieved then analized qualitatively by using Miles and Huberman interactive data analysis method. Whereas, the resul of the data from assessment rubric were analyzed by using interrater agrrement model method or Gregory's Formula.

\section{RESULT AND DISCUSSION}

In this study, it was founded six learning models of Hindu illumination technique based spiritual tour guide, such as: Dharma Sadhana. Sadhana means practice and experience. So, Dharma Sadhana is express dharma by practice or experince of religion or dharma doctrin. It was implementated through Catur Marga, they are: Bhakti Marga, Karma Marga, Jnana Marga, and Yoga Marga. Direct learning model was a learning model emphasized on concept mastery and / or behaviour alteration prime on deductive approach, with caracterized by: (1) directly tranformation and skills; (2) oriented learning to a specific purpose; (3) constructed learning material; (4) constructed learning society; (5) construct by teacher / lecturer / instructor.

Steps or syntax of direct learning models according to Bruce and Weil (1996) were: (1) oreintation, in the learning context of Dharma Sadhana model in Hindu illumination based spiritual tour guide, so that lecturer with the university student do the orientation to the place will be visited, kinds of activities will be done, and decided resource person in "pasraman", "geria", Hindu centre or other place; (2) presentation, in the learning context of Dharma Sadhana model in Hindu illumination based spiritual tour guide, so that the university student made a note of observation result in the field of the information given by the resource person at the place of direct learning observation were done, and hopefully, it could directly show what was done by the resource person in "pasraman", "geria", Hindu centre or other places; (3) constructed training, in the learning context of Dharma Sadhana learning model in Hindu illumination based spiritual tour guide, so that the resource person gave any correction to the student participation in doing the activities which were showed by the resource person in "pasraman", "geria"; Hindu centre or other places: (4) guidance training, in the learning context of Dharma Sadhana learning model in Hindu illumination based spiritual tour guide, so that the resource person gave guidance to the exercise or tasks given; (5) and selftraining, in the context of learning model in Hindu illumination based spiritual tour guide, so that the students could do the activities which were learned stand-alone at home and in the society.

Dhamagita it self is a song or holly canticle, which is mostly related with realization of Yadnya ceremony / religion ceremony, and others traditional arts such as mask (topeng), arja dance, and puppet. In addition, Dharmagita is not only as holly canticle to escort religion ceremony, but also it can be used and developed as learning while singging method (melajah sambilang magending and magending sambilang melajah). This development of Hindu illumination based spiritual tour guide learning model will produce:
(1) learning conceptual model which based on theoritical concept and intoduction study; (2) experimental expert model, this theoritical concept is completed again based on experience and limited experiment; and (3) final model which already to be used based on evaluation study in wider abbys, that is a model which can be used as orientation by the lecturer of Hindu illumination subject.

Dharma Yatra, that is effort to enhance of understanding and experience on Hindu learning through direct worship to holly places. It can be meant as the place which is related with dharma, that need to be visited by Hindu's people. Due to this visit of 'dhamma' place so dhamma (dharma) yatra means to visit holly places which directly related with various importans events. In Bahasa we can mention as Dharma tour. Development of the Hindu illumination learning model through dharma yatra will produce: (1) learning conceptual model based teoritical concept; and (2) expert trial model, it was completed based on experience. Dharma Tula (discussion) is Hindu doctrine thoughful method trough religion discussion. It is quite different with saint discussion. Understanding a religion start from 'sraddha' and 'bhakti'. A good Dharmatula should based on three anvils, so that the dialogue can improve Hindu doctrine understanding quality.

Learning process in the classroom can be post by realize 'Dharma Santi' as what it is done by Hindu people after Nyepi, New Year of 'Çaka'. In learning process, the students act as comitee, master of ceremony, resource person, moderator, notes of meeting and others. Lecture actvities post as real 'Dharma Santi' combine with realization of 'Dharma Tula' or discussion then followed by 'silahturahmi', shaking hands of apologize. Teaching - learning process with 'Dharma Santi' learning model based spiritual tour guide consists of seven steps, They are: (1) tell the learning purpose; (2) organize the students act in 'Dharma Santi'; (3) translator determination; (4) guide the students in 'Dharma Santi' realization; (5) do 'Dharma Tula' (discussion); (6) apologize (silahturahmi); and (7) evaluate and give advises. The lecturer's duties in this class only as observer, guide and evaluator, activities are mostly done by the students. The purpose of this learning is in order to programe the learning in 'Dharma Santi' which involve strangers, can realize 'Dharma Santi' in the classroom, can master one of the topics used as material of 'Dharma Wacana' as well as more understand means of 'Dharma Santi' and can apologize among them, cause human is not escaped from mistakes.

Dharma Wacana can be equal with speech. Dharma Wacana or speech tells about something of Hindu holy book by sistematic words, logical and iteresting so the viewers or listeners can know, understand, and realize Hindu doctrine. In modern ways, Dharma Wacana can be package by technique, method, information and communication media to be more inovative, efective, and productive. It is called creative dharma wacana which is based on principles and modern learning purpose, in order to: learning to 
know, learning to do, learning to be, and learning to live together. The development of Hindu illumination learning model through creative dharma wacana based spiritual tour guide will produce: (1) conceptual learning model based on theoritical concept and introdution study; (2) expert trial model, it was completed based on experience and limited experiment; and (3) final model which have already used based on evaluation study in wider abbys, that is a model can be used as an orientation by the lecturer of Hindu illumination subject, if the illumination is conected with spiritual tour guide.
Learning model prototype of Hindu illumination subject based spiritual tour guide was also validated by the learning expert (Dr. I Nengah Dwi Endra Suanthara, M.Pd) a lecturer of STKIP Agama Hindu Singaraja. Validation sheet which was given to the multimedia experts in the form of Questionare reference five convertion of likert scale, accomodate six aspects, they are: investigator, illumination materia, illumination media, illumination object, illumination effects and illumination disturbance. Those six aspects were explained into 14 indicators. The recapitulation of validation result by the larning expert were showed on Table 1 and Table 2.

Table 1

Learning Quality Criteria

\begin{tabular}{lc}
\hline \multicolumn{1}{c}{ Score } & Category \\
\hline $\mathrm{X} \geq 65,25$ & Very Good \\
$50,75 \leq \mathrm{X}<65,25$ & Good \\
$36,25 \leq \mathrm{X}<50,75$ & Averange \\
$21,75 \leq \mathrm{X}<36,25$ & Bad \\
$\mathrm{X}<21,75$ & Very Bad \\
\hline
\end{tabular}

Table 2

\begin{tabular}{clc}
\multicolumn{4}{c}{$\begin{array}{c}\text { Recapitulation of Validation Score Result by Learning Expert } \\
\text { Learning Quality Criteria by Learning Expert }\end{array}$} \\
\hline No & \multicolumn{1}{c}{ Aspects } & Skor Learning Expert \\
\hline 1 & Investigator & 9 \\
2 & Illumination materia & 10 \\
3 & Illumination media & 10 \\
4 & Illumination object & 14 \\
5 & Illumination effects & 15 \\
6 & Illumination isturbance & 9 \\
\hline \multicolumn{2}{r}{ Total score } \\
\hline
\end{tabular}

Score Quantification result of learning expert to the quality developed were achieved 67 score, it was mean that the quality in learning model of Hindu illumination subject based spiritual tour guide was categorized very good, where the quality of this learning seriously bridge the university students to discover self-potential to become a qualified investigator for Hindu's people.

The quality of learning, model design usage in Hindu illumination subject based spiritual tour guide, after pass the validation steps by the experts and revised as advises given, the next step was realized field-experiment for the efectiveness use of learning model of Hindu illumination subject based spiritual tour guide which were felt by the students. The experiment was done directly when learning process of Hindu illumination Technique Subject Occured, representative by 10 students of STKIP Agama Hindu Singaraja, by note it was agreed with Dick and Carrey theory (2015).

In field-experiment with limited group could be done by involve 10 students, in composition 3 students from upper group, 4 middle group, 3 of beneath group. The sample removal used sampling purposive technique (Sugiono, 2011). So, from this experiment it could be found the lack of the product trial and could quickly be evaluated to become perfection.

From the result which was achieve during the trial, it could be seen that the product tested was still weak. Fisrt, it was the students problem which mastery English yet, so when speaking practice related the spiritual tour guide was found many mistakes in pronounce vocabularies, uncorrect intonation, and gesture or body language when speaking. Second, difficult vocabularies and grammatical aspects. Whereas, from the lecturer side (product user), it was found many mistakes in using English, cause if we look from the educational background, the lecturer who teach Hindu Illumination Technique Subject was not from English education background.

In otherhand, if we look from the excess of this product there were some respondents judge that by practice the Hindu Illumination Spiritual Guide, make the respondents more steady in understanding Hindu doctrine values as orientation become a tour leader of foreign tourist; by constantly propose the spiritual value. Certainly, it becomes a new opportunity if someday enter a field of tourism industry especially in Bali which is strong with religious and culture nuance. So, it can be concluded that this sylabus design is very Qualified to improve the students ability in learning to become a Hindu investigator bilingually.

Beside that, the lecturer of Hindu illumination subject (product user) also said that the tendency of traveling motivation shift from refreshing traveling or vocation into cultural traveling more over to spiritual traveling. It can not be denied because more and more tourist get bored with traveling pacages which offer boisterousness, luxurious, and precious

Only now a days, they learn to pleasant the traveling which offer therapy, meditation, historical archaeological site visit, residence of local native 
people visit, observe the religion ceremonies, trip to holy places to get accurate information, to get serenity, comfortable, and the harmony of mind, soul and physic. This opportunity should be captured by the student who soon became a investigator as major duty and it is supplied by qualified tour guide skill as well as can communicate to the tourist well.

By employing sylabus design of Hindu illumination subject based spiritual tour guide can minimize miss understanding between the tour leader and the tourist which is caused by their limited information. So the tourist do not use their common sense over and over again in giving explanation related to the question. It will impact to dissatisfaction of the tourist. As a consequence, money of service or tip that they get are felt uncomparable with their service to the tourist.

\section{CONCLUSION AND SUGGESTION Conclusion}

This study developed and produced 6 Hindu illumination based spiritual tour guide learning models, such as: (1) Dharma Sadana learning model, visiting spiritual training/ sadhana place, the student mixed up with training / sadhana directly and also act as interpreter explain to the tourist as spiritual sadhana devoted; (2) Dharma Gita learning model, the spiritual lesson devotee learn by singing, pray by singing, and Canticle/gita to escort the praying. The students sing, pare the meaning exist in gita, and involve all spiritual devotee in all gita activities; (3) Dharma Yatra learning model, learn about philosopy, ethic and Hindu's ceremonies by visiting holy place and holy man, so the explaination of an object it self, and after the tirta yatra finish. It can be create in "spiritual package tour" and the student as the tour guide; (4) Dharma Tula learning model, it is a hot issue, problems concerning with Hindu appear internaly and externaly are discussed in dharma Tula to produce strategic policies, urgent, and functional. The student is trained as the organizer of dharma Tula from preparation till the end of the activities; (5) Dharma Santi learning model, the students is trained to realize. Dharma Santi as education of character event to build inner heart, to be mutually, to overlook, to love, to create self peace fulness, family, society, and to keep the nature in harmony. Spiritual devotee tourists are involved also in dharma santi and the student as interpreter; and (6) Dharma Wacana learning model, giving speech about Hindu lesson to the religious community or the tourist as spiritual devotee of Hindu.

This learning model is mostly used, so the student is trained individualy to fullfill the requirement of pedagogic competence, professional, social, and personality. Dharma wacana learning model is create to be interesting, warm, humoris, consists of monologue iteraction, dialogic, and multidialogic, score calculation result by the expert of learning to the quality which was developed, it was achieve 67, it means that the quality of Hindu illumination learning moedl based spiritual tour guide was catagorized very good, where the quality of this learning seriously brigde the student to discover self-potential to became a qualified investigator for Hindu's people.

\section{Sugesstions}

Based on the above conclution, there are some suggestions to be put forward as follows:

1. The lecturer is suggested to purpose the learning model as optimum and give priority to the exercise or the training.

2. The lecturer of this subject is suggested as team teaching and mastering English well.

3. The quality of English subject (sks) semester credit system is suggested to be added, priority in English for guiding to sucessful Hindu illumination learning model based spiritual tour guide.

4. The models which are produced from this study is suggested to be developed, completed again by wider study so really efective and efisient to give characteristic, speciality, and an excellent apart as alternative competetion which can open new job vacancy after the student graduate.

5. Since the quality of alumnus illumination department very evident and quickly judged by the user from their ability to give providing information by using the 6 models, it is suggested to conduct periodic training, planning and organizing from the lecturer team collaborate with the head of department.

\section{REFERENCES}

[1] Anderson, B. R. G. 2000. Mithology and the Tolerance of the Javanese. Cornel Modern Indonesia Project. Yogyakarta: Qalam.

[2] Borg, W. R., \& Gall, M. D. 1989. Educational Research. New York: Longman.

[3] Brown, J. S. 2005. New Learning Environments for the 21st Century. Retrieved December 9, 2016, from http://www.johnseelybrown.com/index.html.

[4] Cudamani. 1997. Pengantar Agama Hindu untuk Perguruan Tinggi. Jakarta: Yayasan Wisma Karma.

[5] Djamarah, S. B. 2002. Rahasia Sukses Belajar. Jakarta: PT Rineka Cipta.

[6] Fraenkel, J. R., and Wallen, N. E. 1990. How to Design and Evaluate Research in Education. New York: McGraw Hill Inc.

[7] Jauhari, M. 2011. Implemntasi PAIKEM dari Behavioristik sampai Konstruktivisme. Jakarta: Prestasi Pustaka Raya.

[8] Maimudin, Y. 1980. Metode Diskusi. Jakarta: Departemen Pendidikan dan Kebudayaan.

[9] Pendit, N. S. 1976. Bhagawadgita. Jakarta: Departemen Agama RI.

[10] Pitana, G. 2012. Wisata Spiritual Potensial Dikembangkan. Retrieved December 9, 2016, from http://travel.kompas/read/2012/08/02/1923017/.

[11] Prastowo, A. 2012. Panduan Kreatif Membuat Bahan Ajar Inovatif, Menciptakan Metode Pembelajaran yang Menarik dan Menyenangkan. Jogyakarta: DIVA Press.

[12] Putra. 2004. Cudamani II Kumpulan Kuliah Agama Hindu Jnana Marga Mrenghayati Tuhan dengan Berfilsafat. Denpasar: Upada Sastra.

[13] Putra. 2005. Cudamani III Kumpulan Kuliah Agama Hindu Bhakti Marga Cinta Kasih dan Penyerahan Diri Kepada Tuhan. Denpasar: Upada Sastra. 
[14] Putra. 2006. Materi Kuliah Agama Hindu di Perguruan Tinggi. Denpasar: Upada Sastra.

[15] Sardiman, A. M. 1986. Interaksi dan Motivasi Belajar Mengajar. Penerbit: Jakarta: Rajawali.

[16] Sastrawijaya, A. T. 1991. Pengembangan Program Pengajaran. Jakarta: PT Rineka Cipta.

[17] Sanjaya, W. 2007. Strategi Pembelajaran Berorientasi Standar Proses Pendidikan. Jakarta: Kencana Prenada Media Group.

[18] STKIP Agama Hindu Singaraja. 2014. Pedoman Studi Prodi Penerangan Agama Hindu 2014. Singaraja: STKIP Agama Hindu Singaraja.

[19] Sudirga, I. B. 2007. Widya Dharma Agama Hindu. Jakarta: Ganeca Exact.

[20] Sugiyono. 2011. Metode Penelitian Kuantitatif, Kualitatif, dan $R \& D$. Bandung: Alfabeta.

[21] Sugeng, P. 1981. Teknik Diskusi dan Aspek-aspek yang Pelu Diperhatiakan dalam Pelaksanaanya. Jakarta: Departemen Pendidikan dan Kebudayaan.

[22] Sukadi. 2012. Pengembangan Potensi Pariwisata Spiritual berbasis masyarakat local di Bali. Research Report. Singaraja: Undiksha.

[23] Tim Penyusun. 1993. Pedoman Pembinaan Umat Hindu Dharma Indonesia. Denpasar: Bidang Urusan dan Penerangan Agama Hindu Kantor Wilayah Departemen Agama Propinsi Bali.

[24] Tim Penyusun. 1999. Pedoman Penyuluh Agama Hindu. Denpasar: Bidang Urusan dan Penerangan Agama Hindu Kantor Wilayah Departemen Agama Propinsi Bali.

[25] Tomlinson, B. 1998. Material Development in Language Teaching. Cambridge: Cambridge University Press.

[26] Trianto. 2010. Mendesain Model Pembelajaran Inovatif-Progresif. Jakarta: Kencana.

[27] Trianto. 2007. Model-model Pembelajaran Inovatif Berorientasi Konstruktivistik (Konsep, Landasan TeoriPraktis dan Implementasinya). Jakarta: Prestasi Pustaka. 